\begin{tabular}{|c|c|c|c|c|c|}
\hline \multicolumn{3}{|c|}{$\mathrm{ROOC}-\mathrm{CH}_{2}-\mathrm{CH}_{2}-\mathrm{COOR}$} & \multicolumn{3}{|c|}{ Activity* } \\
\hline$R=$ & & m.p. & H.D.D. & L.D. & R.P.D. \\
\hline $\begin{array}{r}I \\
\text { II } \\
\text { III } \\
\text { IV } \\
\text { VI } \\
\text { VII } \\
\text { VII } \\
\text { IX }\end{array}$ & 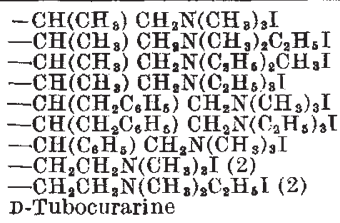 & $\begin{array}{l}222-24^{\circ} \\
174-75^{\circ} \\
163-65^{\circ} \\
229-30^{\circ} \\
232-33^{\circ} \\
202-3^{\circ} \\
222-23^{\circ} \\
252-54^{\circ} \\
195-96^{\circ}\end{array}$ & $\begin{array}{l}30 \\
10 \\
7 \\
5 \\
8 \\
7 \\
30 \\
0 \cdot 2 \\
0.8 \\
0 \cdot 18\end{array}$ & $\begin{array}{l}46 \\
20 \\
10 \\
10 \\
10 \\
10 \\
40 \\
1 \\
1.5 \\
0 \cdot 2\end{array}$ & $\begin{array}{r}180 \\
90 \\
40 \\
40 \\
20 \\
15 \\
- \\
1 \\
3 \cdot 5 \\
0 \cdot 075\end{array}$ \\
\hline
\end{tabular}

* H.D.D. : head drop dose in mgm./kgm. \} obtained by intravenous injection L.D.: lethal dose in $\mathrm{mgm}$./kgm. to obtain curarization.

compounds are shown in the accompanying table, together with the results of the preliminary investigation of their pharmacological properties.

It is noteworthy that in this series the curare activity of the triethylammonium compounds (V, VI) is the same as, or greater than, that of the correspond. ing trimethylammonium salts (I-IV), in contrast with the choline derivatives, where opposite results were obtained ${ }^{2}$. Moreover, the curare activity of the compounds we investigated is less intense and of longer duration.

Details of the preparation and pharmacological properties of these compounds will be published elsewhere.

Since writing this communication we have received the results of the chemical analysis of the newly synthetized compounds: they show that the proposed formulæ are correct.

I wish to acknowledge the Sociéte Anonyme R.I.S.T. and M. G. Derudder for help in the chemical part of this work, and MM. Empain and Vandenberg for some of the pharmacological assays.

Laboratory of Pharmacology,

\section{H. VANDERHAEghE:}

University of Louvain. Nov. 20.

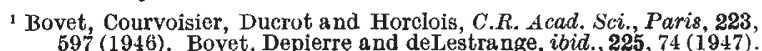
597 (1946). Bovet, Depierre and deLestrange, $i b i d$, , 225, $74(1947)$ Bovet, Bovet-Nitti, Guarind

* Simonart, $J$. Pharmacol., 46, 157 (1932). deLestrange and Lévy. Bull. Sci. Pharmacol., 36, 353 (1929).

\section{Thiocyanate and Endemic Goitre}

THE amount of thiocyanate has been determined in the blood of volunteers from Sumperk in Moravia and Roudnice in Bohemia, two districts in Czechoslovakia where the incidence of endemic goitre is high. In Sumperk, the investigations were carried out in both spring and autumn, but in Roudnice in the autumn only. The Roudnice district has a greater production and consumption of fruit and vegetables.

The findings in the accompanying table show the average thiocyanate-levels in subjects with normal thyroids, with slight hyperplasia and with medium and large goitres. The last two lines show the average thiocyanate values in the autumn in subjects with evidence of vascularization of a goitre and with definite evidence of thyrotoxicosis. Smokers were excluded because the thiocyanate values were found to be increased, without evident hyperplasia of the thyroid gland, in direct proportion to the consumption of cigarettes.

It is evident from the table that the average thiocyanate values in each individual group are greater in the autumn, and also that there is an obvious relation between hyperplasia of the thyroid and its vascularization and activity.

The thiocyanate values of the serum corresponded to those found in subjects who had been given less than $0.1 \mathrm{gm}$. potassium thiocyanate per os over a long period. This dose had no goitre-producing effect even when administered for a long time. The increase in the thiocyanate-level in the blood without corre. sponding increase in the hyperplasia of the thyroid is explained by the view that the inhabitants consume not only foods containing a substance which leads to an increase in the thiocyanate-level in the serum but also certain quantities of a goitre-producing substance which we have not yet been able to identify. Since the thiocyanate-values are greatest in the autumn when the consumption of fruits and vegetables is greatest, we consider that the substance comes from fresh produce.

The results show that, apart from iodine deficiency, endemic goitre has other biochemically detectable causes.

\section{KAREL SILINK}

L. Maršíková

Central Endocrinological Institute,

Štěpánská 27, Prag II. Nov. 16.

' Barker, J. Amer. Med. Assoc., 108, 762 (1936).

\section{Gram-positive Cells of the Human Anterior Pituitary}

THe following is a preliminary report upon an investigation which is being carried out upon the reaction of the glandular cells of human anterior pituitary to Gram's stain.

Interest in this subject arose from $(a)$ the brief statement, in a recent paper by Pearse ${ }^{1}$, that the basophil cells of the human pars distalis are Gram-positive, and $(b)$ the extensive biochemical investigations of Stacey and his colleagues ${ }^{2,3}$, which suggest that the retention of the dye by certain Gram-positive bacteria is to be correlated with the presence of ribosenucleoprotein material in association with their cell membranes.

\begin{tabular}{|c|c|c|c|c|c|c|}
\hline & \multicolumn{4}{|c|}{ May 1950} & \multicolumn{2}{|c|}{$\begin{array}{l}\text { Roudnice district } \\
\text { September } 1950\end{array}$} \\
\hline & $\begin{array}{l}\text { No. of persons } \\
\text { investigated }\end{array}$ & $\begin{array}{c}\text { CNS } \\
\text { (mgm. \%) }\end{array}$ & $\begin{array}{l}\text { No. of persons } \\
\text { investigated }\end{array}$ & $\begin{array}{c}\text { CNS } \\
(\operatorname{mgm} . \%)\end{array}$ & $\begin{array}{l}\text { No. of persons } \\
\text { investigated }\end{array}$ & $\begin{array}{c}\text { CNS } \\
\text { (mgm. \%) }\end{array}$ \\
\hline Subjects with normal thyroids & 13 & $0 \cdot 115$ & 19 & $0 \cdot 248$ & 32 & $0 \cdot 265$ \\
\hline $\begin{array}{l}\text { Subjects with slight hyperplasia (prom- } \\
\text { inence less than } 2 \mathrm{~mm} \text {.) }\end{array}$ & 92 & $0 \cdot 220$ & 82 & 0.309 & 72 & $0 \cdot 371$ \\
\hline $\begin{array}{l}\text { Subjects with medium or large goitre } \\
\text { (prominence more than } 2 \mathrm{~mm} \text {.) }\end{array}$ & 38 & $0 \cdot 333$ & 36 & 0.337 & 41 & $0 \cdot 391$ \\
\hline $\begin{array}{l}\text { Subjects with evidence of increased } \\
\text { vascularization of the thyroid giand }\end{array}$ & - & - & 1 & $0 \cdot 360$ & 4 & $0 \cdot 478$ \\
\hline $\begin{array}{l}\text { Subjects with deflnite evidence of } \\
\text { thyrotoxicosis }\end{array}$ & - & - & 11 & $0 \cdot 368$ & 5 & 0.510 \\
\hline
\end{tabular}

